\title{
"The land is a healer": Perspectives on land-based healing from Indigenous practitioners in northern Canada
}

\author{
Jennifer Métisse Redvers, Institute for Circumpolar Health Research (ICHR)
}

Cultural knowledge is currently being revitalized by Indigenous practitioners where land is understood as a relational component of healing and wellbeing. Land-based activities such as harvesting, education, ceremony, recreation, and cultural-based counselling are all components of this integrative practice. Land-based practices are centered in Indigenous pedagogy and recognize that identity is interwoven with and deeply connected to land. Formally cultivating this fundamental relationship increases positive mental health and wellness outcomes in Indigenous populations as assessed through a culturally relevant lens. This research paper articulates a cultural concept described here as "land-based" healing or wellness which has been understood and taught for millennia by Indigenous knowledge holders and has largely remained undefined within mainstream mental health promotion and intervention. In this study, qualitative narrative methods were used to document the experiences of eleven land-based program practitioners from three northern territories in Canada. As experts in this field, practitioners' narratives emphasized the need for a greater understanding and recognition of the value of land-based practices and programs within contemporary health and education systems. The development of working definitions, terminology, and framing of land-based healing and wellness practices as a common field is delineated from relevant literature and practitioner narratives in order to enable crosscultural communication and understanding in psychology. Land-based healing is presented as a critical and culturally appropriate method for mental health intervention and community resilience in northern Canada.

Keywords: Mental health, intervention, land-based healing, health promotion, Indigenous knowledge, Northern Canada, land-based pedagogy, resilience

\section{Glossary}

Land-based: Relationship with the land as a central feature or concept rooted in Indigenous epistemology and pedagogy. Land-based implies a deep connection with and non-separation between human beings and the natural world. A reference to land includes all aspects of the natural world: plants, animals, ancestors, spirits, natural features, and environment (air, water, earth, minerals). The term can also be used in reference to a physical location or geographical concept.

Land-based healing: A culturally defined practice, program, or service that takes place in an urban nature-based, rural, or remote location, on a land base that has been intentionally spiritually cultivated, honoured, and respected (Hanson, 2012). The land is situated as firmly relational within an Indigenous pedagogy, and is understood to be an active "partner to the person or people engaged in the healing process" (Hanson, 2012, p. 2). Steps are taken to identify how an individual or community's relationship with the land, self, and others has been disrupted and how best to help renew this relationship (Laurie, 2013). This has also been referred to as "land-based intervention" in the literature (Walsh et al., 2018).

Land-based program: A culturally defined program or service that takes place in an urban nature-based, rural, or remote location, which involves cultural teachings and 
intergenerational knowledge transfer, combined with any number of other activities or goals. Programs are informed by an Indigenous pedagogy wherein the land is the main source of knowledge and teaching.

\section{Acknowledgements}

This study was completed as part of my graduate degree at the University of Calgary under the dedicated supervision of Dr. Mary-Ellen Tyler. I would like to extend gratitude to all the participants who offered their time and wisdom to this project, as well as others who shared their stories with me as I travelled throughout the north. I am thankful for the mentorship of Dene and Tlingit Elders, colleagues at the Institute for Circumpolar Health Research, and Nathaniel Pollock at the University of Alberta. Student funding was provided through a team grant in CommunityBased Primary Health Care from the Canadian Institutes of Health Research (CIHR) and by the University of Calgary Faculty of Environmental Design. I gratefully acknowledge cultural and inkind research support from the Qaujigiartiit Health Research Centre, the Dene Nation, and the Nunavut Research Institute. 


\section{Introduction}

Indigenous knowledges and ways of life are embedded in the land (Tobias \& Richmond, 2014; Wildcat et al., 2014; Zoe, 2012). Environmental health is a determinant of human health (Cunsolo et al., 2015; Durkalec et al., 2015) and connection to the land is recognized as a central feature in Indigenous health and well-being (Kant et al., 2013; Richmond \& Ross, 2009).

Rebuilding a sense of connection with the land is important for Indigenous mental health promotion and intervention (Kirmayer et al., 2003; Walsh et al., 2018).

Indigenous peoples in Canada are revitalizing land-based initiatives to strengthen community resiliency and address challenges arising from a continuing legacy of colonization and landdispossession (Ballantyne, 2014; Ilisaqsivik, 2014; Mikraszewicz \& Richmond, 2019; Takano, 2005; Thompson et al., 2018; Tidlumaluk, 2007). These initiatives are "rooted in the land, traditional knowledge, spiritual values and ceremonial practice" (Walsh, 201, p. 209).

\section{Land-Based Programs as Mental Health Promotion and Intervention}

In order to promote wellness in Indigenous communities, it is vital to reconnect with cultural identity and practices within an Indigenous pedagogy (Simpson, 2014; Stewart, 2008). According to Stewart (2008), Indigenous conceptions of mental health and healing must be incorporated into counselling, therapy, and other efforts in promoting Indigenous mental health. This includes framing mental health holistically, within physical, emotional, and spiritual aspects (Lavallee \& Poole, 2009;

McCormick, 2000). The study of resilience is a strength-based way of framing mental health intervention in communities (Goodkind et al., 2012; Kirmayer et al., 2011; Wexler et al., 2009) by focusing on building socio-ecological networks and protective factors that strengthen cultural ties and identity (Allen et al., 2013;

Andersson \& Ledogar, 2008; Tousignant \& Sioui, 2009). Indigenous conceptions of psychological resilience recognize the importance of a "person's relations with others and the environment" (Kirmayer et al., 2009, p. 63). The importance of culture and community-led interventions are widely recognized throughout the field of psychology, including responding to youth suicide (Chandler et al., 2003; Kirmayer et al., 2003; Menzies, 2008; Wexler \& Gone, 2012).

Land as a central dimension of wellness is embedded in Indigenous knowledge, and is a necessary foundation for culturally responsive mental health care in Indigenous communities (Dobson \& Brazzoni, 2016; Redvers et al., 2019). Northern Canada faces many barriers to health care delivery, including limited access to culturally relevant health services and the challenge of service provision in remote locations (Oosterveer \& Young, 2015; Redvers et al., 2019; Young et al., 2019). As such, many communities are turning to land-based healing and wellness programs (Dobson \& Brazzoni, 2016; Hirsch et al., 2017; Hond et al., 2019; Laiti \& Sorbye, 2013; Luig et al., 2011; Radu et al., 2014; Smethurst, 2012; Thunderbird Partnership Foundation, 2018). Evaluations have demonstrated that land-based programs increase resilience and wellness in youth by improving self-esteem, interpersonal relationships, and cultural pride (Healey et al., 2016; Janelle et al., 2009; Ritchie et al., 2014). There is still a need for more crosscultural research around the conceptualization, design, delivery, and evaluation of these initiatives (Ritchie et al., 2014) with a call to invite more of those involved to share their stories in the literature (Walsh, 2018). 
The objectives of this study were to: (1) articulate the epistemological foundations of land-based healing and wellness in northern Canada; and (2) explore practice-based definitions of land-based programs in the context of Indigenous mental health promotion and intervention.

\section{Methods}

\section{Conceptual Framework}

An Indigenous research methodology was employed in this study, drawing on qualitative research tools which were most convergent (Kovach, 2010; Lowan-Trudeau, 2012) with my own Dene ontology. Despite rich cultural diversity, common aspects and beliefs are found within the research paradigms of Indigenous peoples (Wilson, 2008). Central to this paradigm is the importance of storytelling as a way to represent lived experience, and the importance of building respectful research relationships (Mehl-Madrona, 2005; Wilson, 2008). Smith (2012) explains that an Indigenous research approach takes a political stance on research, recognizing the historical context of oppression and exclusion of Indigenous values found in dominant research paradigms. I recognize the historical exclusion of Indigenous and multicultural voices within mainstream psychology and a need for the articulation of Indigenous voices and knowledges within proposed research and interventions (Gergen \& Gulerce, 1996).

\section{Study Setting}

The Northwest Territories, Yukon, and Nunavut are the three territories of Canada (Please see Figure 1). Collectively, they represent $39 \%$ of the total land mass of Canada, with $0.3 \%$ of the national population, and the three highest per capita Indigenous populations (Statistics Canada, 2016). There are 18 official Indigenous languages spoken and over 24 community and regional First Nations, Métis, and Inuit governments (Government of Canada, 2017).

\section{Figure 1}

Yukon, Northwest Territories, and Nunavut

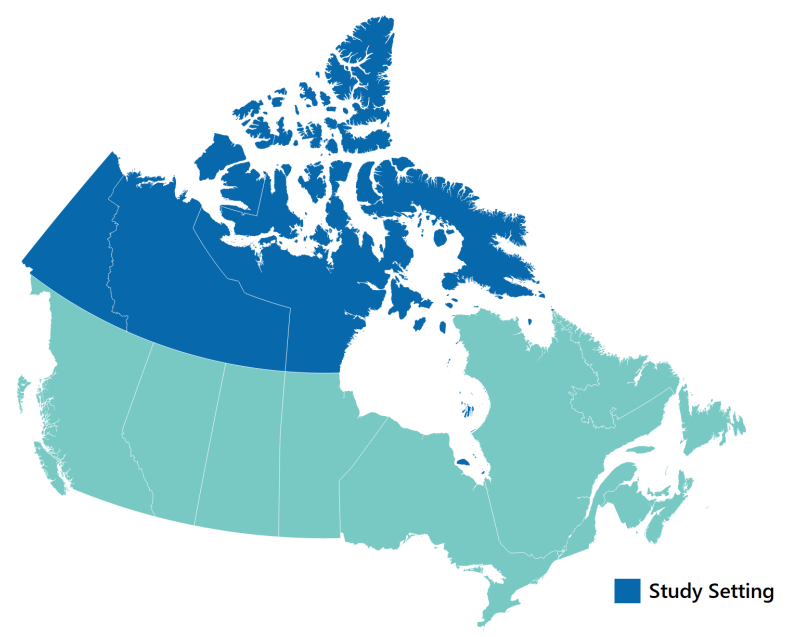

\section{Participant Selection}

I interviewed 11 Indigenous experts in land-based programming from 10 different nations across the study area. The participants represented diverse genders, ages, First Nations, Métis, and Inuit backgrounds. Participants were chosen through purposive sampling, an intentional selection of community-vetted experts and a subsequent 'snowball strategy' (Polkinghorne, 2005, p. 140).

\section{Relationship Building}

Positionality is important in

Indigenous methodologies (Lowan-Trudeau, 2012). I identify as Denesųłıné from the Northwest Territories (NWT), and my own connection to this field and worldview informed the research conceptualization. I had prior professional relationships with six of the participants and approached my work with known participants as an "insider" (Innes, 2009). This was countered by my "outsider" status as a researcher (Smith, 2012) and, at times, differences among our own cultural backgrounds. Time was spent 
building relationships with all participants, including travelling out on the land when invited.

Ethics approval for this study was obtained through the University Conjoint Faculties Research Ethics Board, and detailed community feedback sought through two research licence applications with the Aurora Research Institute and the Nunavut Research Institute. Elder mentors were consulted throughout the study.

\section{Data Collection and Analysis}

\section{In-Depth Interviews}

Audio-recorded, in-depth semistructured interviews (Please see Table 1) took place in five different communities. The interview questions were translated into Inuktitut for Inuk participants.

\section{Table 1}

\section{Interview Guide}
1. Why has creating opportunities for Indigenous youth, adults, and/or Elders to spend time out on the land been important to you?

2. What do you think is an appropriate way of referring to these land-based initiatives?

3. Can you share with me some positive experiences or stories from your work in this field?

4. Has your experience been that there are health benefits from all the programs or bush trips you have been involved with, or do some activities or programs provide more benefits than others?

5. What are some of the personal barriers you have experienced in organizing programs or land practices in your community?

6. What would you like to see happen in the future with land-based health initiatives?

7. Is there anything else you feel is important or that I missed?

\section{Preliminary Analysis}

A process of narrative analysis was used for working with transcripts (Clandinin, 2013). The initial transcripts were sent back to the participants in draft format for clarification and feedback before becoming final copies (Clandinin, 2013). Important narratives from the informants were kept intact as much as possible in the research texts (Kovach (2010, p. 52). I utilized thematic analysis to generate themes from the final transcribed texts (Braun \& Clarke, 2006; Kovach, 2010). My theoretical framing was within Indigenous ways of knowing with aspects of a social constructivist paradigm, which "values context in cultural construction of knowledge, language and communication" (Stewart, 2008, p. 50).

\section{Final Analysis and Dissemination}

To organize participant stories into a coherent format, broader themes and subthemes were identified (Braun \& Clarke, 2006). During the analysis, I looked for connections between the experiences of participants in order to find commonalities across different geographic and cultural regions. Final results were presented back to the participants for feedback. Plain language summaries were completed for knowledge sharing in each geographic territory.

\section{Results}

Practitioners shared their extensive knowledge about land-based practices and assisted in framing the work they do into a common field of practice, which I will refer to as "land-based" healing and wellness. They were deeply grounded in their cultures and saw their own resilience and languages as rooted in a relationship with the land. The nuances of bringing land-based practices into the contemporary systems of education, health, and justice were described in detail. Participants shared stories and materials, 
including unpublished program reports on at least forty different land-based programs, including pilot programs and multi-year initiatives. They described land-based programming as an intricate, crossdisciplinary, and highly developed field of professional practice. As one program manager stated:

There is so much groundwork that needs to be done. You can't just go out and set up a tent and start a fire, I mean it's so much more than that. I don't think people realize how much more to it there is.

\section{Epistemology}

The term "land-based" was described as a reminder of humanity's fundamental and inherent connection with the natural world and was agreed upon as a common English term across all regions for crosscultural dialogue. This was after an acknowledgement of the diverse terminology describing land in each traditional language. This culturally-infused term differentiated the concept from western-based conceptions of nature which were seen to approach humans and the land as separate entities. For example, one practitioner explained, "it's a weird thing because we will say, we will go out in nature, but what the heck are we? We are nature, we can't get out in nature." See Table 2 describing this concept in detail.

\section{Table 2}

\section{Land-Based Epistemology}

Practitioner Quotes

Land-based is one of those words, it's a beautiful, wonderful term. It is bringing people back to the land and helping them become alive and remembering their humanity and their connection to all living things. We are the land. So, if we remember who we are, then the same miracle that we see all around us, will be us.

At some point, my grandmother...she told lots of stories about the land, the life of the land. She spoke to me one time, I might have been about 13, and she'd talk about how... we were the land, not from it, but we are the land. That I was the earth and I was the fire, and I was the water and I was the air, and all of them were things that contributed to give me life. And so, without any one of them I would not be able to exist.

The knowledge holders explained that the land is a healer, and described its central role in physical, mental, emotional, and spiritual health. They talked about its inherent connection with their way of being and seeing the world through their own landbased (traditional) languages. Further to this, they emphasized the "experiential language" of the land and described "land-based" as a lived connection built over generations, shared through the oral tradition, and understood only through direct practices or experiences.

\section{Terminology}

It was noted that the term "land-based" provided a foundational term that could be followed by any number of words including "program", "practice”, "camp", "activity", "education”, "pedagogy", "resilience”, "health", "wellness", "healing", or "skills", describing different concepts united in an Indigenous epistemology. These designations were made for organizational and practical considerations within different program areas. All practitioners indicated that a "land-based program" ultimately promoted healing and wellness regardless of its disciplinary origins, and identified a need for more conceptual clarity around this. One program manager stated: 
I'm always thinking of how to explain things in certain ways to funders... and I think it [having a common term] would be useful in terms of articulating what we do and why it's important. To have some kind of term, or a way that can concisely convey what it is, the model, that includes the health components and the education components together as one.

\section{Land-Based Programs}

Within land-based practices, there was a distinction made between activities and programs. Many activities continue to be lived as a way of life including berry picking, ceremonial gatherings, and hide tanning. When it came to operating programs or services more formally through various organizations, the importance of programming was recognized. It is important to note that this recognition was not always comfortable, with practitioners noting an unfortunate irony within the contemporary context, specifically, that they now have to tailor their way of life into the Western concept of a "program" in order for this way of life to continue (please see Table $3)$.

\section{Table 3}

Importance of Land-Based Programs

\begin{tabular}{|l|}
\hline Practitioner Quotes \\
\hline I've been in this position where I try to \\
find...third party funding to come in and pull \\
people together. So that I provide the \\
resources, what's needed for the exchange to \\
happen for youth and Elders to be able to \\
connect, just to facilitate what naturally \\
happened for thousands of years, now you \\
need to do it in a very formal kind of way...and \\
then we have to go out and fight to create these \\
opportunities. It's really kind of sad that you \\
have to do things this way, but it's become \\
necessary I guess.
\end{tabular}

Because there are some people who aren't fortunate to be able to go out on the land with their families, and so often, those organized trips are the only opportunities for them.

Do we need to do this to help them [our people] to understand? If it takes 'program,' then let's do it. And later on, we'll just call it life...a program called life.

Throughout the interviews, six common elements of successful land-based programs were mentioned by the practitioners. These elements are presented in Figure 2.

\section{Figure 2}

Common Elements of Successful Land-based Programs

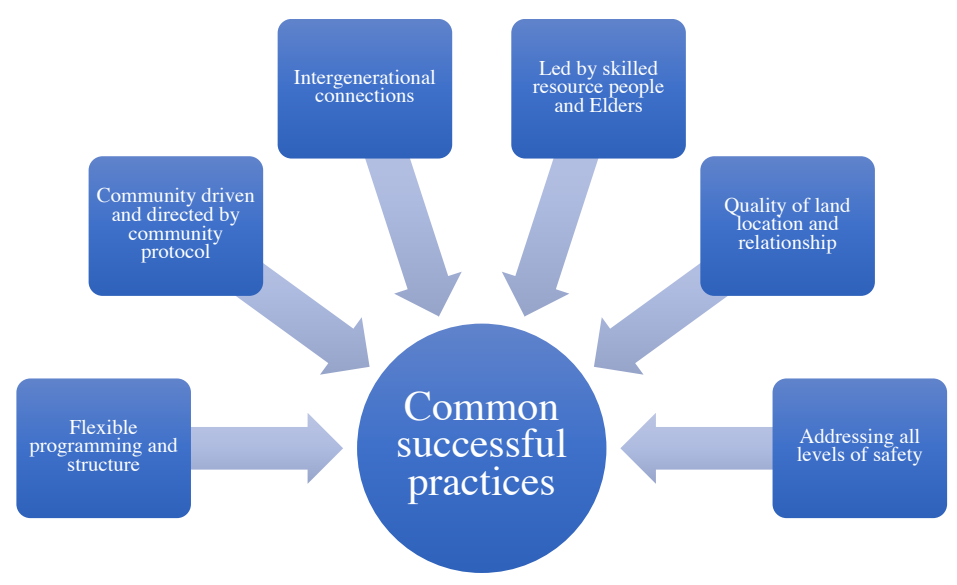




\section{Land-Based Healing}

"Land-based healing" was the term used that most closely aligned for application within the field of mental health. One practitioner explained this concept:

For me, I think that land-based healing is remembering who you are. I think it's returning to that place, becoming who you really are, and getting out of the illusion, or the stuff that the world taught us. I think land-based healing is remembering. It is when you can become...when you start to remember who you are by your connection.

Land-based healing programs were organized within various organizations as supportive interventions for a range of mental health outcomes including addictions treatment and complex trauma recovery. All programs highlighted the importance of the land as beneficial to health at the individual and community level. The practitioners observed that people who participated showed improved health and social outcomes related to self-esteem, physical fitness, interpersonal relationships, educational goals, feelings of positive health and wellbeing, positive behavioural changes, connection to cultural identity, traditional language skills, and interest in environmental stewardship. Practitioners shared a vision for land-based activities continuing and expanding as a core way of addressing intergenerational healing and overall wellbeing. The main themes common across the conceptualization and operation of land-based healing programs are presented in Table 4.
Table 4

Land-Based Healing Program Subthemes

\begin{tabular}{|l|l|}
\hline Subthemes & Practitioner Quotes \\
\hline $\begin{array}{l}\text { The innate } \\
\text { ability of the } \\
\text { land itself }\end{array}$ & $\begin{array}{l}\text { The land will heal people. } \\
\text { What I know, is that when I } \\
\text { bring a group of people out } \\
\text { on the land, the land knows } \\
\text { exactly who they are, they } \\
\text { know exactly what they are } \\
\text { struggling with. May not } \\
\text { know it intellectually, but it } \\
\text { knows it on a way deeper } \\
\text { level than the intellectual. }\end{array}$ \\
\hline $\begin{array}{l}\text { The } \\
\text { importance } \\
\text { of traditional } \\
\text { healing and } \\
\text { spirituality }\end{array}$ & $\begin{array}{l}\text { Why we believe in it so } \\
\text { much, because going back } \\
\text { there [to traditional land } \\
\text { location] brought, what we } \\
\text { hear people saying, it } \\
\text { brought a sense of belonging } \\
\text { and it helped a lot of people } \\
\text { in their memories of } \\
\text { residential school. It helped } \\
\text { them to remember and } \\
\text { connect with who they were } \\
\text { prior to being taken away to } \\
\text { the residential schools. }\end{array}$ \\
\hline $\begin{array}{l}\text { Combining } \\
\text { western } \\
\text { therapeutic } \\
\text { supports }\end{array}$ & $\begin{array}{l}\text { We had people saying, } \\
\text { to a shrink, no way!", and I } \\
\text { said, "No problem", I said } \\
\text { "just come out to [the } \\
\text { camp]". And then next thing } \\
\text { you know, they are walking } \\
\text { down the lake talking with } \\
\text { the psychiatrist or the } \\
\text { therapist and they are doing } \\
\text { therapy and they don't } \\
\text { realize it. }\end{array}$ \\
\hline
\end{tabular}

\section{Professional Expertise}

Finally, five areas were identified by practitioners as professional challenges which require expertise to navigate in landbased program operation (please see Table $5)$. 
Table 5

Land-Based Program Professional Challenges

\begin{tabular}{|c|c|}
\hline Subthemes & Practitioner Quotes \\
\hline $\begin{array}{l}\text { Cross-cultural } \\
\text { barriers defining } \\
\text { outcomes and } \\
\text { importance }\end{array}$ & $\begin{array}{l}\text { One of the biggest differences I see is that most of the time government } \\
\text { programs are designed to be this age group, or this type of clientele. It is really } \\
\text { compartmentalized. In terms of what we do, we see benefits straight across the } \\
\text { board, from even the most challenging child or teenager...or an adult who has } \\
\text { been struggling for a long time...And all we'd have to do is we'd tell them } \\
\text { some stories... and that's our proof. }\end{array}$ \\
\hline $\begin{array}{l}\text { Accessing funding } \\
\text { and resources }\end{array}$ & $\begin{array}{l}\text { I think making sure the resources are there, and the money is } \\
\text { definitely a stressor... a camp can cost up to } \$ 30,000-\$ 40,000 \text {. } \\
\text { It's almost like government will fund other things or will fund people } \\
\text { who have Masters, PhDs, or some-called professional, and will offer } \\
\text { a workshop here and will pay for that, but they don't want to give } \\
\text { money to our Elders. And they are our greatest teachers, and we have } \\
\text { to cherish this knowledge, but we don't get the recognition in terms } \\
\text { of support for funding. }\end{array}$ \\
\hline Logistics and safety & $\begin{array}{l}\text { Logistically there's a lot of safety concerns with bringing a bunch of } \\
\text { people out on the land who don't have much land-based } \\
\text { experience... so there's a lot of that to manage, well and safely. } \\
\text { What's been a challenge is the reporting process... the administration } \\
\text { aspects of holding out on the land programs. }\end{array}$ \\
\hline $\begin{array}{l}\text { Intensity and } \\
\text { unique challenges } \\
\text { of the work }\end{array}$ & $\begin{array}{l}\text { When I first started doing them [running land-programs], I didn't } \\
\text { [really enjoy it], it was a lot of work, so much work.....at the } \\
\text { beginning when you are in the planning process, and dealing with all } \\
\text { the logistics and stuff, you are super stressed out. } \\
\text { And the more people want it [land-based healing] ...that's where it's scary if } \\
\text { it's person dependent. Because our spiritual counselor, he's just one guy....and } \\
\text { he can't work } 365 \text { days a year and give give give....It could have the tendency } \\
\text { that it could be really hard on them. }\end{array}$ \\
\hline $\begin{array}{l}\text { Colonial disruption } \\
\text { of knowledge } \\
\text { transmission }\end{array}$ & $\begin{array}{l}\text { Getting people into the program and out on the land a lot of times it's really } \\
\text { challenging in a bunch of different ways, like physically challenging... but for } \\
\text { a lot of young Indigenous people it's challenging because they get out there } \\
\text { and realize "Hey, no one ever taught me how to fillet a fish, like why can't I do } \\
\text { that?" "No one ever taught me how to set a fish net, why? Why do I not know } \\
\text { how to do this, I'm a native person, and I can't. I've never fired a gun, I don't } \\
\text { know how to hunt, and I don't know how to fish and I can't even start a fire } \\
\text { right now!", and I think it triggers a lot of feelings of shame which is pretty } \\
\text { difficult to deal with. }\end{array}$ \\
\hline
\end{tabular}




\section{Future Directions}

All practitioners were committed to the work they do and motivated to overcome the many issues of cultural inequity in the current health and education systems. Ultimately, the hope is for these initiatives to become more commonplace and for all community members, Indigenous and nonIndigenous, to benefit from the inherent wisdom being used to restore collective health.

You know... one time my brother got up to talk at a meeting. He said, "You know why I do this work?" He said, "I do this work for the less fortunate." And then he waited for a small while and he said, "Don't get me wrong, I am not talking about street people, I'm not talking about people who don't have a home or people that are having a hard time", he says, "I am talking about the less fortunate; I am talking about doctors and lawyers and judges, that's who I do this work for," he said, "because they don't know."

(Practitioner quote)

\section{Discussion}

Many northern Indigenous communities have been vocal in their understanding that reconnecting people with land practices is a preferred mode of healing (Porter, 2012; "Yukon to invest", 2014). Both informal activities and contemporary programs are united under an integrated and culturally-determined epistemology, referred to in this study and corresponding literature as "land-based" (Dylan \& Smallboy, 2016; Thompson et al., 2018; Walsh et al., 2018; Wildcat et al., 2014). For Indigenous practitioners, this cultural understanding differentiates it from other terms in the literature such as "outdoor", "adventure", "wilderness" or "nature-based" (Russell, 2001) which stem from Western conceptualizations and values of land ethic, often including a laden separateness or "stewardship over" (DeLancey, 2012) rather than interdependence with the natural world (Lowan, 2009). Lowan (2009) provides a detailed discussion of some of the key differences attributed to place from an Indigenous Canadian context, including describing the deep historical and spiritual relationship with the land which lives on through place names, languages, and storytelling.

Land-based programming, as described in this study, is a highlydeveloped field of practice, informed by Indigenous epistemologies within Indigenous communities. Fundamental to this are Indigenous ways of teaching and learning. Wildcat et al. states "Land-based education, in resurging and sustaining Indigenous life and knowledge, acts in direct contestation to settler colonialism and its drive to eliminate Indigenous life and Indigenous claims to land" (Wildcat et al., 2014, p. 111). Further, land-based pedagogy acts through engagement in direct conversations with and "on the land in a physical, social and spiritual sense" (p. 11).Through this direct engagement, participants helped articulate the concepts and healing benefits behind land-based healing, which are similar to those provided in other studies across Canada (Dobson \& Brazzoni, 2016; Gesink et al., 2019; Hansen, 2018; Radu et al., 2014; Tobias \& Richmond, 2014; Walsh et al., 2018). The land as healer wisdom held by knowledge keepers is now recognized in the literature demonstrating a myriad of scientifically validated health and wellness outcomes stemming from spending time connecting with natural areas (Barton et al., 2016; Barton \& Pretty, 2010; Berman et al., 2008; Bratman et al., 2012; Bratman et al., 2015; James et al., 2015; Li, 2010; Maller et al., 2006). This key finding demonstrates the 
connection between culturally-validated knowledge around human-land relationships and the scientific evidence base.

The dispossession of land and culture through colonization and residential schools has fundamentally affected Indigenous mental health in Canada (Kant et al., 2013; Kirmayer et al., 2003) and participants in this study described many aspects of this disruption. The forcible alteration of the connection between land and identity, which sustains a sense of well-being, is within living memory in northern Canada with the last residential school closing in the late 1990's (Igloliorte, 2011; Wilk et al., 2017). With this in mind, participants' knowledge provides support for the value of land-based healing as vital to the reconciliation process in Canada (Walsh et al., 2018). This includes not just the recognition of different vocabulary around "land-based" but the validation of a rich history and interconnectedness between land, languages, knowledges, health, and people, all of which are experienced through a living connection with traditional lands. The available literature and narratives presented provide evidence that land-based programs are a socially acceptable and culturally safe form of therapeutic care in Indigenous communities. In this case, recognition of 'practice-based' evidence becomes a relevant way of validating this field combined with the increasing evaluative data (Healey et al., 2016; Janelle et al., 2009; Ritchie et al., 2014). This means using "real-life practice as a basis for building evidence" (Sahota \& Kastelic, 2012, p.108). This finding has direct applications for mental health policy.

\section{Barriers to Accessing Land-Based Healing}

Practitioners articulated that landbased activities continue to be a part of everyday life for people who have the time, knowledge, and resources. However, there are diverse contemporary conceptual and physical barriers to accessing the land and taking part in activities. Walsh et al. (2018) describes many challenges of practice, including costs; liability insurance;

transportation; specialized labour; payments for Elders; strict rules and regulations of funding bodies; issues around the use of firearms; and programs not being considered mental health interventions (Walsh et al., p. 215). These concerns are echoed by northern practitioners.

The narratives presented highlight the concern that mental health service provision still operates in a westerndominated discourse, compartmentalizing services and creating a narrow view of mental health, and more specifically what practices are considered counselling and therapy (Hadjipavlou et al., 2018). This discourse is largely defined by western understandings of mental health and the language of evidence-based practice (EBP), which is still so often interpreted as empirically supported treatments (Carter \& Goodheart, 2012; Laska et al., 2014). The result is mental health interventions that rely on systematic reviews, large effect sizes, statistical, and clinical significance (Sahota and Kastelic, 2012, p. 107). These facets of empirical evidence are often unrealistic to obtain in remote northern communities and culturally inappropriate (Janelle et al., 2009; Smith, 2012). Stewart (2008) points out that due to the disconnect between Indigenous and western approaches, and despite high needs in many communities, mental health services are underutilized in comparison to non-Indigenous populations in Canada. Further, the counselling of Indigenous people from non-Indigenous worldviews and frameworks has been presented as a form of continued colonial oppression, while discrediting traditional understandings of health and healing (Stewart, 2008). 


\section{Land-Based Healing and Wellness}

Land-based healing and wellness programs are conceptually highly-developed and offer an alternative and complement to current mental health services and approaches to therapy (Dobson \& Brazzoni, 2016; Walsh et al., 2018). Many of the cultural counsellors and Elders involved in these programs are in high demand in their respective communities, but not recognized as professionals by mainstream counselling organizations or licensing authorities. This study supports a call for the equitable inclusion of cultural counsellors in the strategy to improve care of Indigenous clients in the Canadian health care system (Hadjipavlou et al., 2018). Land-based interventions have the potential to draw on local strengths and keep people who need help close to home, instead of being sent to larger communities for mental health services (GNWT, 2014). Success is noted in the flexible program design, cultural competence, and the expertise of the people involved.

The rich narratives in this field illustrate many forms of integrative practice and opportunities for coexisting interventions that are feasible or currently operating in a range of communities (Walsh et al., 2018). A single program is able to address a range of related mental, physical, social, educational, and environmental concerns. For example, programs can offer culturally relevant addictions support, family counselling, rehabilitation of offenders, physical fitness, environmental stewardship, and life skills training. They also include benefits for cross-cultural professional training and awareness (Mashford-Pringle \& Stewart, 2019). Indigenous youth are notably a key demographic for land-based interventions who benefit at all levels of land-based health promotion, prevention, and service delivery (Allen et al., 2013; Chandler \& Lalonde, 1998; Corntassel \& Hardbarger, 2019; Healey et al., 2016; MacDonald et al., 2013). I have proposed some working definitions as a way of framing this dialogue in the glossary.

I propose that discussions around culturally relevant intervention at the policy level should continue to acknowledge the reality and significance of Indigenous land connection within all levels of mental health service, from promotion to treatment, counselling and aftercare. This would continue to build on the ground-breaking work in recognizing the potential of Indigenous-led mental health solutions by many organizations, including the Aboriginal Healing Foundation, Thunderbird Partnership Foundation, and initiatives such as the Northwest Territories on the Land Collaborative. Creating opportunities and spaces for "land-making" within urban centres (Hatala et al., 2019) and land-based connection within counselling sessions or treatment programs are recommended as culturally relevant sources of therapy and resilience (Hadjipavlou et al., 2018; Stewart, 2008). Further research is recommended in order to increase our collective understanding and renegotiate the terminology and working definitions proposed for cross-cultural dialogue across Turtle Island ${ }^{3}$, keeping in mind the rich diversity within Indigenous communities.

\section{Limitations}

The three northern territories in this study are large, and although efforts were made to represent diverse knowledge groups, logistics limited the dataset of practitioners who could be interviewed to specific regions, therefore desired terminology may differ across communities.

${ }^{3}$ Turtle Island refers to the continent of North America. 
There is also a wealth of land-based terminology in the 18 traditional languages spoken throughout the study region which wasn't captured in this research. I feel it is important to note here, that in many areas of Canada, traditional land-access and land rights are severely restricted, with direct implications for this field of research, and knowledge is highly contextualized to place. This research examined narratives specifically from a northern Indigenous perspective and, although commonalities do exist in cultural teachings across Turtle Island, there is much diversity in these knowledges and land contexts, which will further inform this study's ability to be generalized to other locations. Finally, an Elder advisor reminded me of a limitation to this topic of research, stating that it is a concept that is ultimately "beyond words."

\section{Conclusion}

This study outlined the experiences of northern Indigenous practitioners in the field of land-based healing and wellness. In order to rediscover and re-establish a fundamental relationship with the land, one must first experience it directly through practical, culturally-rooted activities, languages, and interactions that return us to the land physically, emotionally, mentally, and spiritually. By bringing land connection to the forefront in the dialogue within Indigenous mental health in Canada, we can draw on the resilience of the land itself to more effectively overcome ongoing impacts of colonization and land-degradation. A healthy land relationship not only ensures the land's health, it also facilitates healthy relationships within ourselves, between one another, and within the larger world, leading to greater balance and mental wellbeing for future generations.

\section{References}

Allen, J., Hopper, K., Wexler, L., Kral, M., Rasmus, S., \& Nystad, K. (2013). Mapping resilience pathways of Indigenous youth in five circumpolar communities.

Transcultural Psychiatry, 1-31. https://doi.org/10.1177/1363461513497232

Andersson, N., \& Ledogar, R. J. (2008). The CIET Aboriginal youth resilience studies: 14 years of capacity building and methods development in Canada. Pimatisiwin: A Journal of Aboriginal and Indigenous Community Health, 6(2), 65-88. http://www.pimatisiwin.com/online/?page_i $\mathrm{d}=228$

Ballantyne, E. F. (2014). Dechinta Bush University: Mobilizing a knowledge economy of reciprocity, resurgence and decolonization. Decolonization: Indigeneity, Education \& Society, 3(3), 6785.

https://jps.library.utoronto.ca/index.php/des /article/view/22238

Barton, J., Bragg, R., Pretty, J., Roberts, J., \& Wood, C. (2016). The Wilderness Expedition. Journal of Experiential Education, 39(1), 59-72. https://doi.org/10.1177/1053825915626933

Barton, J., \& Pretty, J. (2010). What is the best dose of nature and green exercise for improving mental health? A multi-study analysis. Environment, Science and Technology, 44, 3947-3955. https://doi.org/10.1021/es903183r

Berman, M., Jonides, J., \& Kaplan, S. (2008). The cognitive benefits of interacting with nature. Psychological Science, 19(12). https://doi.org/10.1111/j.14679280.2008.02225.x

Bratman, G. N., Hamilton, J. P., \& Daily, G. C. (2012, Feb). The impacts of nature experience on human cognitive function and mental health. Ann N Y Acad Sci, 1249, 118-136. https://doi.org/10.1111/j.17496632.2011.06400.x

Bratman, G. N., Hamilton, J. P., Hahn, K. S., Daily, G. C., \& Gross, J. J. (2015, Jul 14). Nature experience reduces rumination and subgenual prefrontal cortex activation. Proc 
Natl Acad Sci U S A, 112(28), 8567-8572. https://doi.org/10.1073/pnas.1510459112

Braun, V., \& Clarke, V. (2006). Using thematic analysis in psychology. Qualitative Research in Psychology, 3, 77-101. https://doi.org/10.1191/1478088706qp063o a

Carter, J. A., \& Goodheart, C. D. (2012). Interventions and evidence in counseling psychology: A view on evidence-based practice. In APA handbook of counseling psychology, Vol. 1: Theories, research, and methods. (pp. 155-166). https://doi.org/10.1037/13754-006

Chandler, M. J., \& Lalonde, C. (1998). Cultural continuity as a hedge against suicide in Canada's First Nations. Transcultural Psychiatry, 35(2), 191-219. https://doi.org/10.1177/1363461598035002 02

Chandler, M. J., Lalonde, C. E., Sokol, B. W., \& Hallett, D. (2003). Personal persistence, identity development, and suicide: A study of Native and Non-native North American adolescents. Monogr Soc Res Child Dev, 68(2), vii-viii, 1-130; discussion 131-138. https://doi.org/10.1111/1540-5834.00246

Clandinin, D. J. (2013). Engaging in narrative inquiry (1st ed.). Routledge. https://doi.org/10.4324/9781315429618

Corntassel, J., \& Hardbarger, T. (2019). Educate to perpetuate: Land-based pedagogies and community resurgence. International Review of Education, 65(1), 87-116. https://doi.org/10.1007/s11159-018-9759-1

Cunsolo, W., A., Stephenson, E., Allen, J., Bourque, F., Drossos, A., Elgarøy, S., Kral, M., Mauro, I., Moses, J., Pearce, T., MacDonald, J., \& Wexler, L. (2015). Examining relationships between climate change and mental health in the Circumpolar North [Original Paper]. Regional Environmental Change, 15(1), 169. https://doi.org/10.1007/s10113-014$0630-\mathrm{z}$

DeLancey, C. (2012). An Ecological Concept of Wilderness [Article]. Ethics \& the Environment, 17(1), 25-44. https://doi.org/10.2979/ethicsenviro.17.1.25 Dobson, C., \& Brazzoni, R. (2016). Land based healing: Carrier First Nations' addiction recovery program. Journal of Indigenous Wellbeing, 1(2), 9-17. https://journalindigenouswellbeing.com/jou rnal_articles/land-based-healing-carrierfirst-nations-addiction-recovery-program/

Durkalec, A., Furgal, C., Skinner, M. W., \& Sheldon, T. (2015). Climate change influences on environment as a determinant of Indigenous health: Relationships to place, sea ice, and health in an Inuit community. Soc Sci Med, 136-137, 17-26. https://doi.org/10.1016/j.socscimed.2015.04 .026

Dylan, A., \& Smallboy, B. (2016). Land-based spirituality among the Cree of the Mushkegowuk territory. Journal of Religion \& Spirituality in Social Work: Social Thought, 35(1-2), 108-119. https://doi.org/10.1080/15426432.2015.106 7589

Gergen, K. J., \& Gulerce, A. (1996). Psychological science in cultural context [Article]. American Psychologist, 51(5), 496. https://doi.org/10.1037/0003066X.51.5.496

Gesink, D., Whiskeyjack, L., \& Guimond, T. (2019). Perspectives on restoring health shared by Cree women, Alberta, Canada. Health Promot Int, 34(3), 454-461. https://doi.org/10.1093/heapro/dax099

GNWT. (2014). Healing voices: The Minister's forum on addictions and community wellness. D. o. H. a. S. S. Government of the Northwest Territories. https://www.hss.gov.nt.ca/sites/hss/files/mi nisters-forum-addictions-report.pdf

Goodkind, J. R., Hess, J. M., Gorman, B., \& Parker, D. P. (2012). "We're still in a struggle": Dine resilience, survival, historical trauma, and healing. Qual Health Res, 22(8), 1019-1036. https://doi.org/10.1177/1049732312450324

Government of Canada. (2017). Indigenous peoples and communities https://www.rcaanccirnac.gc.ca/eng/1100100013785/15291024 90303

Hadjipavlou, G., Varcoe, C., Tu, D., Dehoney, J., Price, R., \& Browne, A. J. (2018). “All my relations": experiences and perceptions of Indigenous patients connecting with 
Indigenous Elders in an inner city primary care partnership for mental health and wellbeing. Canadian Medical Association Journal, 190(20), E608. https://doi.org/10.1503/cmaj.171390

Hansen, J. (2018). Cree Elders' perspectives on land-based education: A case study. Brock Education Journal, 28, 74-91. https://doi.org/10.26522/brocked.v28i1.783

Hanson, G. (2012). Strong woman's voices: Final report Jackson lake land based healing women's program AugustSeptember 2012 (Building a path to wellness). Kwanlin Dun First Nation. http://www.kwanlindun.com/images/upload s/KDFN\%20Building\%20a\%20Path\%20to $\% 20$ Wellness $\% 20$ -

$\%$ 20Evaluation\%20Final\%20Report $\% 2020$ 12.pdf

Hatala, A. R., Morton, D., Njeze, C., BirdNaytowhow, K., \& Pearl, T. (2019). Reimagining miyo-wicehtowin: Human-nature relations, land-making, and wellness among Indigenous youth in a Canadian urban context. Soc Sci Med, 230, 122-130. https://doi.org/10.1016/j.socscimed .2019 .04 .012

Healey, G. K., Noah, J., \& Mearns, C. (2016). The Eight Ujarait (Rocks) Model: Supporting Inuit Adolescent Mental Health With an Intervention Model Based on Inuit Ways of Knowing. International Journal of Indigenous Health, 11(1). https://doi.org/10.18357/ijih111201614394

Hirsch, R., Furgal, C., Hackett, C., Sheldon, T., Bell, T., Angnatok, D., Winters, K., \& Pamak, C. (2017). Going Off, Growing Strong: A program to enhance individual youth and community resilience in the face of change in Nain, Nunatsiavut.

Études/Inuit/Studies, 40(1), 63-84. https://doi.org/10.7202/1040145ar

Hond, R., Ratima, M., \& Edwards, W. (2019). The role of Maori community gardens in health promotion: a land-based community development response by Tangata Whenua, people of their land. Glob Health Promot, 26(3_suppl), 44-53.

https://doi.org/10.1177/1757975919831603

Igloliorte, H. (2011). "We were so far away":

Exhibiting Inuit Oral Histories of
Residential Schools. In E. Lehrer, C. E. Milton, \& M. E. Patterson (Eds.), Curating Difficult Knowledge. Palgrave Macmillan Memory Studies,. https://doi.org/10.1057/9780230319554_2

Ilisaqsivik. (2014). "Land based programming". Retrieved April 21 from http://ilisaqsivik.ca/programs-andservices/land-based-programming

Innes, R. A. (2009). "Wait a second. Who are you anyways?" The insider/outsider debate and American Indian studies. American Indian Quarterly, 33(4), 440-461. www.jstor.org/stable/40388481

James, P., Banay, R. F., Hart, J. E., \& Laden, F. (2015). A Review of the Health Benefits of Greenness. Curr Epidemiol Rep, 2(2), 131142. https://doi.org/10.1007/s40471-0150043-7

Janelle, A., Laliberte, A., \& Ottawa, U. (2009). Promoting traditions: An evaluation of a wilderness activity among First Nations of Canada. Australas Psychiatry, 17 Suppl 1, S108-S111. https://doi.org/10.1080/1039856090294860 5

Kant, S., Vertinsky, I., Zheng, B., \& Smith, P. M. (2013). Social, cultural, and land use determinants of the health and well-being of Aboriginal peoples of Canada: A path analysis [Article]. Journal of Public Health Policy, 34(3), 462-476. https://doi.org/10.1057/jphp.2013.27

Kirmayer, L., Dandeneau, S. F., Marshall, E., Phillips, M. K., \& Williamson, K. J. (2011). Rethinking resilience from Indigenous perspectives. Canadian Journal of Psychiatry, 56(2), 84-91. https://doi.org/10.1177/0706743711056002 03

Kirmayer, L., Sehdev, M., Whitley, R., Dandeneau, S. F., \& Isaac, C. (2009). Community resilience: Models, metaphors and measures. International Journal of Indigenous Health, 5(1), 62-117. https://doi.org/10.1046/j.10385282.2003.02010.x

Kirmayer, L., Simpson, C., \& Cargo, M. (2003). Healing traditions: culture, community and mental health promotion with Canadian Aboriginal peoples. Australasian 
Psychiatry, 11(s1), S15-S23.

https://doi.org/10.1046/j.1038-

5282.2003.02010.x

Kovach, M. (2010). Indigenous methodologies:

Characteristics, conversations, and contexts. University of Toronto Press.

Laiti, T., \& Sorbye, T. S. (2013).

"Meahcceterapiija" adapting the family treatment to an Indigenous Sami population: Camping out with the family.

Proceedings of the 15th International

Congress on Circumpolar Health,

International Journal of Circumpolar

Health, 72(1), 605.

https://doi.org/10.3402/ijch.v72i0.22447

Laska, K. M., Gurman, A. S., \& Wampold, B. E.

(2014). Expanding the lens of evidence-

based practice in psychotherapy: A

common factors perspective.

Psychotherapy, 51(4), 467-481.

https://doi.org/10.1037/a0034332

Laurie, V. (2013). Land based treatment

programs: Promising practices, key

considerations, and ideas for action.

Council of Yukon First Nations Health and

Social Development Department.

http://www.kwanlindun.com/images/upload

s/CYFN\%20Report\%20-

$\% 20$ Land\%20Based\%20Treatment $\% 20$ Pro

grams $\% 20$ -

$\%$ 20Practices, $\% 20$ Considerations $\% 20 \& \% 2$

OIdeas\%20(2013).pdf

Li, Q. (2010). Effect of forest bathing trips on

human immune function. Environ Health

Prev Med, 15(1), 9-17.

https://doi.org/10.1007/s12199-008-0068-3

Lowan, G. (2009). Exploring place from an

Aboriginal perspective: Considerations for outdoor and environmental education.

Canadian Journal of Environmental

Education, 14, 42-58.

https://cjee.lakeheadu.ca/article/view/885

Lowan-Trudeau, G. (2012). Methodological metissage: An interpretive Indigenous approach to environmental education research. Canadian Journal of

Environmental Education, 17, 113-130. https://cjee.lakeheadu.ca/article/view/1082

Luig, T., Ballantyne, E. F., \& Scott, K. K.

(2011). Promoting well-being through landbased pedagogy. International Journal of
Health, Wellness \& Society, 1(3), 13-26.

https://doi.org/10.18848/2156-

8960/CGP/v01i03/41181

MacDonald, J. P., Ford, J. D., Willox, A. C., \& Ross, N. A. (2013). A review of protective factors and causal mechanisms that enhance the mental health of Indigenous

Circumpolar youth. Int J Circumpolar

Health, 72, 21775.

https://doi.org/10.3402/ijch.v72i0.21775

Maller, C., Townsend, M., Pryor, A., Brown, P., $\&$ St Leger, L. (2006). Healthy nature healthy people: 'contact with nature' as an upstream health promotion intervention for populations. Health Promot Int, 21(1), 4554. https://doi.org/10.1093/heapro/dai032

Mashford-Pringle, A., \& Stewart, S. L. (2019). Akiikaa (it is the land): exploring landbased experiences with university students in Ontario. Global Health Promotion, 26(3_suppl), 64-72. https://doi.org/10.1177/1757975919828722

Mehl-Madrona, L. (2005). Coyote wisdom: The power of story in healing. Bear \& Company.

Menzies, P. (2008). Developing an Aboriginal healing model for intergenerational trauma. International Journal of Health Promotion and Education, 46(2), 41-48. https://doi.org/10.1080/14635240.2008.107 08128

Mikraszewicz, K., \& Richmond, C. (2019). Paddling the Biigtig: Mino biimadisiwin practiced through canoeing. Soc Sci Med, 240, 112548. https://doi.org/10.1016/j.socscimed.2019.11 2548

Oosterveer, T. M., \& Young, T. K. (2015). Primary health care accessibility challenges in remote indigenous communities in Canada's North. International Journal of Circumpolar Health, 74(1). https://doi.org/10.3402/ijch.v74.29576

Porter, J. (2012). First Nations seek healing by reconnecting to the land. http://www.cbc.ca/news/canada/thunderbay/first-nations-seek-healing-byreconnecting-to-the-land-1.1149180

Radu, I., House, L. M., \& Pashagumskum, E. (2014). Land, life, and knowledge in Chisasibi: Intergenerational healing in the 
bush. Decolonization: Indigeneity,

Education \& Society, 3(3), 86-105.

https://jps.library.utoronto.ca/index.php/des /article/view/21219

Redvers, N., Marianayagam, J., \& Blondin, B. (2019). Improving access to Indigenous medicine for patients in hospital-based settings: a challenge for health systems in northern Canada. Int J Circumpolar Health, 78(1), 1577093.

https://doi.org/10.1080/22423982.2019.157 7093

Richmond, C. A. M., \& Ross, N. A. (2009). The determinants of First Nation and Inuit health: A critical population health approach. Health \& Place, 15(2), 403-411. https://doi.org/http://dx.doi.org/10.1016/j.he althplace.2008.07.004

Ritchie, S. D., Wabano, M.-J., Russell, K., Enosse, L., \& Young, N. L. (2014). Promoting resilience and wellbeing through an outdoor intervention designed for Aboriginal adolescents. Rural and Remote Health, 14(1), 1-19.

www.rrh.org.au/journal/article/2523

Russell, K. C. (2001). What is wilderness therapy? The Journal of Experiential Education, 24(2), 70-79. https://doi.org/10.1177/1053825901024002 03

Simpson, L. B. (2014). Land as pedagogy: Nishnaabeg intelligence and rebellious transformation. Decolonization: Indigeneity, Education \& Society, 3(3), 125. https://jps.library.utoronto.ca/index.php/des /article/view/22170

Smethurst, T. (2012). Well-being and ethnic identity promotion for Aboriginal youth: A community based mixed methods study of tribal journeys. Thesis Department of Psychology University of Victoria, 1-118. http://voyager.library.uvic.ca/vwebv/holdin gsInfo?bibId=2959572

Smith, L. T. (2012). Decolonizing methodologies: Research and Indigenous peoples. Zed Books Ltd.

Statistics Canada. (2016). Statistics on Indigenous Peoples Statistics Canada, Government of Canada. https://www.statcan.gc.ca/eng/subjectsstart/indigenous_peoples

Stewart, S. L. (2008). Promoting Indigenous mental health: Cultural perspectives on healing from Native counsellors in Canada. International Journal of Health Promotion and Education, 46(2), 49-56.

https://doi.org/10.1080/14635240.2008.107 08129

Takano, T. (2005). Connections with the land: Land-skills courses in Igloolik, Nunavut. Ethnography, 6(4), 463-486. https://doi.org/10.1177/1466138105062472

Thompson, H. A., Mason, C. W., \& Robidoux, M. A. (2018). Hoop House Gardening in the Wapekeka First Nation as an Extension of Land-Based Food Practices. Arctic, 71(4), 407-421. https://doi.org/10.14430/arctic4746

Thunderbird Partnership Foundation. (2018). Land for healing: Developing a First Nations land-based service delivery model. https://thunderbirdpf.org/wpcontent/uploads/2018/07/ThunderbirdpfLandforHealing-Document-SQ.pdf

Tidlumaluk, I. M. (2007). Kayak adventureres deliver message to Inuit youth: Live life! . Inuktitut Magazine, 102, 38-45. https://www.itk.ca/inuktitut-issue-102/

Tobias, J. K., \& Richmond, C. A. (2014). "That land means everything to us as Anishinaabe....": Environmental dispossession and resilience on the North Shore of Lake Superior. Health Place, 29, 26-33. https://doi.org/10.1016/j.healthplace.2014.0 5.008

Tousignant, M., \& Sioui, N. (2009). Resilience and Aboriginal communities in crisis: Theory and interventions. International Journal of Indigenous Health, 5(1), 43-61. https://doi.org/10.3138/ijih.v5i1.28977

Walsh, R., Danto, D., \& Sommerfeld, J. (2018). Land-Based Intervention: a Qualitative Study of the Knowledge and Practices Associated with One Approach to Mental Health in a Cree Community. International Journal of Mental Health and Addiction, 18(1), 207-221. https://doi.org/10.1007/s1 1469-018-9996-3 
Wexler, L. M., DiFluvio, G., \& Burke, T. K. (2009). Resilience and marginalized youth: Making a case for personal and collective meaning-making as part of resilience research in public health. Social Science \& Medicine, 69(4), 565-570.

https://doi.org/10.1016/j.socscimed.2009.06 .022

Wexler, L. M., \& Gone, J. P. (2012). Culturally responsive suicide prevention in Indigenous communities: unexamined assumptions and new possibilities. Am J Public Health, 102(5), 800-806. https://doi.org/10.2105/ajph.2011.300432

Wildcat, M., McDonald, M., Irlabacher-Fox, S., \& Coulthard, G. (2014). Learning from the land: Indigenous land based pedagogy and decolonization. Decolonization:

Indigeneity, Education \& Society, 3(3), I$\mathrm{XV}$.

https://jps.library.utoronto.ca/index.php/des /article/view/22248

Wilk, P., Maltby, A., \& Cooke, M. (2017). Residential schools and the effects on Indigenous health and well-being in Canada-a scoping review. Public Health Rev, 38, 8. https://doi.org/10.1186/s40985017-0055-6

Wilson, S. (2008). Research is ceremony: Indigenous research methods. Fernwood Publishers.

Young, T. K., Chatwood, S., Ng, C., Young, R. W., \& Marchildon, G. P. (2019). The north is not all the same: comparing health system performance in 18 northern regions of Canada. Int J Circumpolar Health, 78(1), 1697474.

https://doi.org/10.1080/22423982.2019.169 7474

Yukon to invest \$1 million in Kwanlin Dun healing camp. (2014, May 28, 2014). Canadian Broadcasting Cooporation. Retrieved May 30 from http://www.cbc.ca/news/canada/north/yuko n-to-invest-1-million-in-kwanlin-dunhealing-camp-1.2657187

Zoe, J. B. (2012). Ekwo and Tlicho Naowa/ Caribou and Tlicho language, culture and way of life: An evolving relationship and shared history. Rangifer Special Issue,
32(20), 69-74.

https://doi.org/10.7557/2.32.2.2253 